\title{
A Critical Appraisal on Flaws in Existing Legal Aid Law: Bangladesh Perspective
}

\author{
Kazi Latifur Reza ${ }^{1}$, Rashed Ahmed ${ }^{2}$, Md. Mamun Chowdhury ${ }^{3}$ \\ ${ }^{1}$ (Lecturer, Department of Law \& Justice, The People's University of Bangladesh, Bangladesh) \\ 2(Assistant Professor, Department of Law \& Justice, The People's University of Bangladesh, Bangladesh) \\ ${ }^{3}$ (Lecturer, Department of Law \& Justice, The People's University of Bangladesh, Bangladesh)
}

\begin{abstract}
For the development of human rights and the protection of constitutional rights of a country, a proper Legal Aid System and its development are essential. Without proper Legal Aid System, ensured access to justice, fair trial, rule of law, fundamental rights, human rights, equality before law and human rights development is not possible. Legal Aid is a form of human rights. It protects the rights of backwards section of human. It also stimulates and encourages their new activities. This article focuses on the present laws ensure legal aid in Bangladesh, to point out the ways through which one can get legal aid, to expose the practical flaws to complied Legal Aid Act and to suggest the recommendations with necessary modifications in the existing Legal Aid Law of circumstances prevailing in our society would best meet our judicial needs and access to get justice in Court.
\end{abstract}

Keywords: Aingoto Sohayota Prodan Ain, Access to Justice, Flaws in Legal Aid, Legal Aid, Legal Assistance.

\section{Introduction}

The augment of welfare state in the twentieth century has brought forward with it the concept of legal aid for those who cannot afford the cost of litigation. Bangladesh is a developing democratic country of the world. The Constitution of the People's Republic of Bangladesh, 1972 has theoretically ensured access to justice, fair trial, and rule of law, fundamental rights, human rights, and equality before law. Now the Bangladesh and international community are becoming increasingly concerned about the welfare state of their citizen. In this regard, the issue 'Legal Aid' is very important. The modern justice system through judicial adjudication is very costly and that cost has been the most difficult factor for the average people to get justice in both developed and developing countries. The third paragraph of the Constitution of the People's Republic of Bangladesh, 1972 states, ".......it shall be a fundamental aim of the state to realize through the democratic process to socialist society, free from exploitation, a society in which the rule of law, fundamental human rights and freedom, equality and justice, political, economic, and social, will be secured for all citizens." This is the reality that the economic condition of the common people forming $90 \%$ of the total population baffles description. The demon illiteracy, poverty and wants have still kept them subjugated and ignorant of basic human rights and amenities. A famous remark ascribed by Darling L.J, "Justice Door is open to all like the Ritz Hotel." This remark lays an age-long complaint that cost of law prevents the poor people from seeking justice. Their fate resolves round the globe of darkness without any better chance. Justice Anser Ali stated, "our poor litigant people, most of whom pass more than half of the year through acute starving condition, cannot afford to reach the doors of any law chamber and derive any benefit of their services in many cases and as a result, they silently bear the agonies and burns of injustice done to them in various spheres of life without any legal relief. This is nothing but a negation to them of one of their fundamental rights of equality before law and the equal protection of Law."But no amount of the constitutional protection can help a poor citizen of a country like ours to protect the rights and liberties unless there is some one to stand by his side to provide legal aid.

\section{Rationale And Objectives Of The Study}

The main objective of this study is to examine the existing situation of legal aid service practices in Bangladesh after some legal developments concerning legal aid issues. To fulfill the main objectives, the following mentioned objectives have been taken into consideration:-

1. To highlight the existing legal frameworks in Bangladesh concerning legal aid issue.

2. To expose the ways and means by which the legal aid can be brought to the poor litigants.

3. To point out the factors responsible to delay in obtaining legal aid.

4. To suggest the recommendations with necessary modification in the existing law provisions deals legal aid. 


\section{Methodology}

For exposing the present situation of legal aid service availed in Bangladesh and the modernized possible way out through which the poor and helpless people can afford legal representation or access to justice in court and to achieve the main objectives of this paper, the study is basically literary based with an overall combination of analytical reasoning. Methodologies for this research study include qualitative as well as to some extend quantitative data processing technique for data collected from publications of concerned authorities, available books, research studies, articles of prominent jurists, key note paper presented in conference, the existing Legal Aid Acts, international agreements, news paper reporting, web sites.

\section{Legal Aid- The Meaning}

The dictionary meaning of the aid is assistance. Subsequently, to common persons, the expression legal aid will stand for legal assistance. The impression legal aid refers to a wide sense and contains counseling, payment of lawyer's fee and other supplementary expenditures for articulates of the litigation. The term "legal aid" is defined in the United Nations Principles and Guidelines as follows:

"Legal aid" includes legal advice, assistance and representation for persons detained, arrested or imprisoned, suspected or accused of, or charged with a criminal offence and for victims and witnesses in the criminal justice process that is provided at no cost for those without sufficient means or when the interests of justice so require. Furthermore, "legal aid" is intended to include the concepts of legal education, access to legal information and other services provided for persons through alternative dispute resolution mechanisms and restorative justice processes". According to the Legal Aid Services Act, 2000 Legal aid connotes the assistance in terms of legal advice, lawyers' fees, litigation costs and other incidental expenses, provided to the economically disadvantaged populations including those who, for various socio-economic considerations, are unable to access justice.

\section{Who Can Apply For Legal Aid}

In the act, there is no reference as to the eligible criteria to get legal aid. Subsequently, the ministry of Law, justice and parliamentary Affairs formulated guidelines and rules under section 24 of the Act to carry out the objectives of the Act. The As per Rule 2 of the legal Aid Rules 2001 the following persons will be entitled to receive legal aid:

1. Any person who is financially incapable or poor means any person whose yearly average income is not more than taka $1,00,000.00$.

2. Any freedom fighter incapable of earring or partly incapable or jobless or whose yearly income is not more than taka. 100,000.00;

3. Any person who is receiving old age benefit

4. Any helpless mother with V.G.D card;

5. Any women or children who are victims of illegal trafficking;

6. Any women or children who are victims of acid throwing

7. Any person who has been allotted a house or plot to any ideal village; Poor widow, any poor women deserted by her husband

8. Any handicapped person with earring incapability;

9. Any person who is financially incapable to protect or defined his rights in the court;

10. Any person who is arrested under preventive detention law and is financially incapable to defend his rights

11. Any person who has been considered by the court financially incapable or poor;

12. Any person who has been considered or recommended by the Jail Authority financially incapable or poor;

13. Any person considered by the Organization from time to time financially incapable or poor for the purpose of the Legal Aid Act.

\section{Application Procedure For Legal Aid}

An application for legal aid shall be made in the manner and form prescribed by National Legal Aid Organization. All Application for getting legal aid must be submitted to the National Board of Legal Aid or in appropriate cases to the District Legal Aid Committee. If an application is rejected by the District Committee and the person feels aggrieved by that decision, the applicant may prefer an appeal to the National Legal Aid Board within 60 days of the pronouncement of the decision of the District Committee. Apart from the previously mentioned provisions, the Legal Aid Rules: 2000 provides for the following for how to make an applicant for Legal Aid. The candidate shall apply, along with his Full name \& address and the underlying causes for his applicant, in a white paper. If the applicant is made for legal aid for any matter in the Supreme Court, it is to be submitted to the Chairman of the organization, on the other hand, if it is for legal aid in any contract, it is to be made to the chairman of the chairman of the Committee. The application accepted by the committee is considered in its next meeting. If it is not possible for the committee to take decision based on the 
submitted information, then the committee may require for further information, and once any application considered to have been accepted, the applicant litigant shall be informed in the prescribed manner.

\section{Supply Of Papers And Documents}

The legal aid lawyers will submit all necessary papers and documents related to the case concerned free of cost except the court fees to the court to whom the applicant is seeking redress.

\section{Panel OF Lawyers}

The provisions as to panel lawyers under the Legal Aid services Act, 2000 are as follows: For the Supreme Court panel would include a group of lawyers who have practice experience not less than 7 years in the High Court Division; for District Court panel would include a group of lawyers who have practice experience not less then 5 years; once an application for legal aid is granted, the Board or committee shall appoint a lawyer from among those in the panel provided that in such appointment will be considered as far as possible.

\section{Fees Of Legal Aid}

As per the Legal Aid Rules, 2001 for conducting legal aid cases legal aid lawyers will get maximum of taka 1000.00 in Bangladeshi currency equivalent to about $\$ 12.5$ dollar for drafting a plaint or memo of appeal; maximum of taka 1000.00 in Bangladeshi currency for drafting of a written statement; maximum of taka 600.00 in Bangladeshi currency equivalent to about $\$ 7.5$ dollar for preparing an application or written statement of any miscellaneous case; maximum of taka 500.00 in Bangladeshi currency equivalent to about $\$ 6.25$ dollar for any interlocutory applications or any reply of thereof; maximum of taka 100.00 in Bangladeshi currency equivalent to about $\$ 1.25$ dollar for any time petition; maximum of taka 500.00 in Bangladeshi currency equivalent to about $\$ 6.25$ dollar for final hearing of a family matter; taka 800.00 in Bangladeshi currency equivalent to about $\$ 10$ dollar for hearing of a civil suit; taka 500.00 in Bangladeshi currency equivalent to about $\$ 6.25$ dollar for argument of a criminal case; and taka 200.00 in Bangladeshi currency equivalent to about $\$ 2.5$ dollar for any urgent application paid out of the legal aid fund. To conduct criminal cases hi courts other than High Court Division the panel lawyers will get paid as per the rate the Assistant Public Prosecutors are paid and for conducting a case in the Supreme Court, maximum of taka 2000.00 in Bangladeshi currency equivalent to about $\$ 25$ dollar.

\section{Composition Of National Legal Aid Organisation}

The Legal Aid Act, 2000 provides an Organization named "National Legal Aid Organization". The Act requires the organization to be formed by notification in official Gazette. The Act provides that the management and administration of the National Legal Aid Organization will be vested on a National Management Board. The head office shall be in Dhaka. .The management board will be headed by a Chairman who is the Minister, Law, Justice and Parliamentary affairs. This Board includes people from all walks of the society starting from Member of Parliament nominated by the Speaker, Attorney General, Secretary of Law, Home and Social Welfare, Inspector General of Police and Prison, Vice-Chairman of the Bar Council, the President of the Supreme Court Bar Association, the Chairman of the National Women Commission, three representatives of any NGO's nominated by the Government working for human rights and legal aid which have activities in Districts with the Director of the Board acting as member secretary. These members will be appointed for 2 years term and the government may remove any of the members from the post without showing any notice.

\section{National Management Board}

Under the provisions of the Legal Aid Services Act, 2000, National Legal Aid Board will mainly act as policy-making authority and will formulate rules and policies to select a person and to provide legal aid to the people who are unable to get justice due to financial crisis and due to different socio-economic reasons, frame the schedule to provide legal aid, take initiative to organize research and educational activities to provide legal aid, telecast different programs in order to create awareness among general people about the availability of legal aid in different print etc. for making people aware of getting legal aid and any other activities necessary for the performance of the above mentioned activities.

\section{Director Of National Legal Aid Organization}

It is provided in the Legal Aid Act, 2000 that the National Legal Aid Organization will have a director who will be appointed by government of Bangladesh and will be responsible for implementation of the decisions of the organization and he discharges his functions in accordance with the directions of the Board. However, the director will appoint employees and staff with prior permission of the Government or the Organization. 


\section{District Legal Aid Committee}

The District Legal Aid Committee is solely responsible to provide legal aid at grass root level subject to the availability of fund from the Government. The committee shall invite application from the seeker of legal aid, screen the applications, determine criterion for provision of legal aid and finally provide legal aid.

\section{Constitution Of The District Legal Aid Committee}

According to the provision of the Act, the District Committee shall consist of 13 members, including District and Session Judge as Chairman, the District Magistrate, the Superintendent of Police (SP) of the District, the District Jail Super, an official of the District Social Welfare, if any, the District Women's and Children's officer if any, the Chairman of the District Women's Federation or his nominee, the President of the District Lawyers Associations, Government Pleader of the District, the Public Prosecutor in the District, Inspector of the District Civil Jail, if any available, one representative from any Charitable Society (NGO) in the District nominated by the Chairman of the District Committee, elected General Secretary of the District Lawyer Association, who will also be member-secretary of the Committee, and also the Chief Metropolitan Magistrate and Metropolitan Police Commissioner if the district is in any Metropolitan City. The tenure of the nominated members of both the National and District Committee shall be for two maximum years and may be removed without reason by the government during the tenure.

\section{Functions Of The District Committee}

As per the provisions of the Legal Aid Act, 2000, the District Legal Aid Committee is responsible to provide legal aid to the people who satisfy the criteria as set up by the Board of Governors and who are unable to get justice due to financial crisis or due to different socio-economic reasons; to set up the conditions on which a successful applicant will get the legal aid; to make initiatives to make the people aware of availability of legal aid; to perform the duty invested by the Board; and any other activities necessary for the performance of these activities.

\section{Upazilla And Union Committee}

The Upazilla Committee and Union Committee will consist of one chairman and 14 other members. All issues relating to the Committee will be set up by the subsequent rules.

\section{Funds For Legal Aid Under Governmental Institutions}

The Act provides for establishment of a legal aid fund for both national and district level. The fund of the Board will come from government, foreign donation, local bodies, any other source such as any organization or companies etc. The amount of fund will be deposited in a government bank in the name of the Board. The amount can be drawn up by the joint signature of the Chairman and the member Secretary of the Board. In cases where necessary the District Committee will get found from this fund. The board will meet all types expenses from this fund. The Board will be able to invest this fund in any project if the government authorized project. Fund of District Committee will be a fund of District Legal Aid Committee consisting of government donation, donation from the local authority, company or person, donation from the foreign organization and any other fund obtained by the Committee from any other sources. According to the provision of the Legal Aid Act, 2000 , financial assistance is to provide to the underprivileged based on the fees they incur; for example, lawyer's court fees and other expenses. The committee that has been formed is responsible to utilize the funds, including criteria for eligibility. Funds are to come from national revenue but the officials responsible believe that external support will be necessary to get the programme up and running.

\section{Recent Development Of Legal Aid In Bangladesh:}

Government legal aid program in the country for the last two years got more effective turn and seem to be functional which includes:

\section{Increasing Lawyer Fee}

It was one of the common criticisms from lawyer's community that the lawyer fee is very poor in legal aid cases. Considering the situation lawyers fee has been increased. For preparing petition of civil and family matters lawyers fee has been proposed as taka.4000, at present it is taka1500. For amendment of written statement of civil and family matters lawyer's fees has been proposed as taka. 5000, at present it is taka.1500. Again, for preparing petition of criminal matters fees of assistant public prosecutor has been agreed to taka 800.00. For preparing admission and revision of application fees has been decided to be fixed as taka 400.00 only in Bangladeshi currency. 


\section{Increasing Eligibility Range Of 'Insolvent Person'}

Considering living standard of common people of Bangladesh where yearly income eligibility range has been increased to taka 80000 in Bangladeshi currency from taka 50000. Recently Government has decided in principle that people whose yearly income does not exceed Tk.100000 for lower Court and 150000 for Supreme Court, are entitled to get help from this fund.

\section{Increasing Eligibility Range Of Freedom Fighters}

Freedom fighter whose yearly income is within taka 150000 in Bangladeshi currency is entitled to get help from this fund.

\section{Flaws \& Draw Backes In The Legal Aid Law}

Though the Government has good intention to provide legal aid through the whole country, yet there are some flaws in the Legal Aid Law .Therefore the radical implementation of the legal aid scheme cannot be achieved at its best success. These defects have been discussed as follows;

1) The Act does not specify cases for which legal aid can be provided.

2) As per section 16 of the Legal Aid Services Act, 2000, all applications for getting legal aid must be submitted to the National Board of Legal Aid or in appropriate cases to the District Committee. The procedure for applying for legal aid by the poor is not practical.

3) The present law compels indigent litigants to travel to the District to get legal aid which is very disadvantageous for them.

4) As per the Legal Aid Rules 2001, for legal aid for any matter in the Supreme Court, application is to be made to the Chairman of the National Legal Aid Organization, i.e. the Law Minister. Making an application to the law Minister seems to be a big hurdle for an indigent client.

5) It has not been clarified in the rules how and to whom an indigent client will approach for legal aid in the Supreme Court matter.

6) The duties and responsibilities of the Coordinator are not defined and his responsibility to report to the District judge is not made mandatory in the Legal Aid Services Act, 2000.

7) There is no provision for any advance payment to Legal aid lawyers. In case of filing new cases under the legal aid scheme, appointed lawyers very often seek prior allocation of fund for payment of court fees and meeting incidental expenses. This is an outstanding factor which requires proper decision. Before filing a suit, the indigent client has to collect many documents which has a cost- consideration involved and which is beyond his means. Condition of five years practice for the empanelment of an advocate as provided in the Act is debarring many young lawyers having attitude to help indigent people and thereby to serve the community. As per the provisions of the Legal Aid Services Act, the client has to choose advocates from the panel of three advocates formed by the committee. Therefore, the client is actually debarred to engage advocate of his own choice.

8) There is no media propaganda about the legal aid and so people are unaware of the government initiative. The lack of awareness about the legal aid scheme and its purpose among the indigent litigants and also among the lawyers and judges in general, is the main obstacle to achieve the objectives of the scheme of legal aid.

9) The Distance between the Bench and Bar makes it complied to work together. The nature of the work of District judge isolates him from the Bar and other officials. Therefore, calling a meeting becomes embarrassing for him as he may expose to uneasy situation.

10) The District judge is disinterested in legal aid program also become it is an extra job on his shoulder without remuneration. Being in the position of the District judge, it is not possible for him to monitor the lawyers and see whether they are discharging their duties properly. Therefore, whether a lawyer is taking money from the client (who is mostly illiterate and ignorant) and also drawing money from the fund is difficult to monitor.

11) The following steps to get the legal aid accepted by the committee takes a long time and a litigant who is poor cannot afford to visit the office to pursue the matter let alone bear the expense of traveling cost and other related expense. Constitution of Committees itself show that it is quite impossible to bring all the concerned people in a proceeding under one umbrella on a particular day. Therefore to hold meetings become a futile exercise. Firstly, it is doubtful whether a poor person can have access to the District judge as there is no specific office to register the complaint. Secondly, it is also doubtful whether after much persuasion with the office clerk the application will actually reach the committee without providing any money to the clerk. Moreover, to prove the insolvency, one has to bring a certificate from the Chairman of the Upazilla which is also a questionable process. 
12) The funds are not allotted every year but according to need. Amounts of unutilized money in forty eight (48) districts under the government of Bangladesh legal aid committee at the end of 1997 was 89,76,185.00 taka according to the Law Ministry. This plainly shows the disinterested of the committees in providing legal aid as most of the fund is un-utilized.

\section{Specific Recommendations And Guidelines To Overcome}

The Legal Aid Service mechanism run by the existing laws of Bangladesh would be great success if the following measures are taken by the government:

i. The National Legal Aid Service head office should be reasonably equipped with a logistic capacity including manpower for monitoring and coordinating network that operates all over the country.

ii. Free legal aid service of the government for the poor and vulnerable remains largely unused and ineffective. As a result, the budget allocated for the district legal aid committees remains unutilized in most cases. The National Legal Aid Service committee and District committee should be strictly ensured to utilize allocated Found.

iii. The District Legal Aid office should be located in the same premises of the District and Session Judge Court so that the aid seekers can communicate without difficulty.

iv. Regular meeting of the National Legal Aid Service committee and District committee should be strictly ensured and monitored.

v. Awareness building regarding government legal aid service should be extended in large and innovative mode over the country through various ways such as print media, electronic media, seminars and symposiums.

vi. The annual reports prepared by the Distinct Legal Aid committee submitting to the head office of the board should be regular, consistent and to be followed a format recommended to be developed by the National Legal Aid Board.

\section{Conclusion}

Equality before the law, equal protection of the law and rule of law are all guaranteed in the Constitution of Bangladesh as the fundamental Rights. If the poor and vulnerable sectors of the people are properly grant legal aid facility, subsequently, it can help to implement fundamental rights of Bangladesh Constitutions. It is improved to do something wrongly before to do nothing flawlessly. An excellent preparation put into practiced today is improved than a great plan left for tomorrow. Hence, the government should expand an impression which should be more favorable to address the flaws of the legal aid service mechanism and to receive determined labors with the NGOs to provide a smooth legal aid for ensuring access to justice among the poor litigants. It is not too misleading if we were to say that ideas without action are worthless. Vision without action is just a daydream. Action without vision is a nightmare. So, the time to think an ordinary poor \& helpless people as a person with dignity $\&$ also to ensure justice for all.

\section{References}

[1]. Halim, Md. Abdul, "The Legal System of Bangladesh", 5 ed. October, 2010 (Dhaka: CCB Foundation, p-313.

[2]. HARrison, KEVIN AND Boyd, TONY. UndERstANDING POLITICAL IDEAS AND MOVEMENTS, PUBLISHED- 2003, MANCHESTER UNIVERSITY PRESS, MANCHESTER, UK, P-109.

[3]. http://archive.thedailystar.net/law/2005/06/03/analysis.htm Time:12;12 pm, Date: 24/10/2014].

[4]. http://www.indiansocialstudies.com/2009/concept-of-legal-aid-social-justice.html, last visited 09 January 2011$]$

[5]. http://www.unodc.org/documents/justice-and-prison-reform/eBook-early_access_to_legal_aid.pdf p- 11, Date- 11/11/14, Time1:01 pm.] Or General Assembly resolution 67/187, Para. 8.

[6]. The Legal Aid Services Act, 2000, sec.2 (a).

[7]. Bangladesh gazette, 21 July 2014, S.R.O NO- 194- Ain/ 2014.

[8]. The Legal Aid rules 2001, see rule- 2.

[9]. Supra note vi, see sec.16.

[10]. Supra note viii, see rule- 3 .

[11]. Supra note vi, see sec.19.

[12]. ibid, sec.15.

[13]. Halim, Md. Abdul, "The Legal System of Bangladesh", $4^{\text {th }}$ ed. (Dhaka: CCB Foundation, 2009), p-318 and The Legal Aid rules 2001.

[14]. Supra note vi, see sec.3.

[15]. Supra note vi, see sec.5.

[16]. ibid, see sec. 4

[17]. ibid, s-6.

[18]. ibid s-7.

[19]. ibid s- 21

[20]. Halim, Abdul \& Siddiki, N.E, "The Legal System of Bangladesh after Separation", 1 st ed. (Dhaka: University Publications Limited, 2008), p-354.

[21]. Supra note vi, see sec.9.

[22]. ibid, s-10.

[23]. ibid, s-21. 
[24]. Supra-vii, rule-6

[25]. http://www.dhakatribune.com/bangladesh/2014/may/21/capita-income-now-1180, 11/25/2014, Time 2:39

[26]. Supra-vi

[27]. Ahmad, Ishrat Azim and Karim, Md. Erdhadul , "Principal Of civil Litigation: Bangladesh Perspective”, First Edition-July 2006, Law Lyceum Publisher, Dhaka, Bangladesh, p-195.

[28]. Ameen, Nusrat, "The Legal Aid Act, 2000: Implementation of Government Legal Aid versus NGO Legal Aid", Journal of the Faculty of Law, Vol: XV, no.2 (Dec.2004), University of Dhaka, p.71.

[29]. Supra note xxviii

[30]. Supra note.iii, see rule-3(2).

[31]. Supra note vi.

[32]. ibid.

[33]. Supra note.v, see sec.15.

[34]. Supra note i, p-326.

[35]. Supra note vi,

[36]. Supra note .iii, p-322.

[37]. ibid, p-323.

[38]. ibid

[39]. ibid

[40]. ibid, p. 357 